See discussions, stats, and author profiles for this publication at: https://www.researchgate.net/publication/333008382

\title{
False foe? When and how code switching practices can support knowledge sharing in multinational corporations
}

Article in Journal of International Management · May 2019

DOI: 10.1016/J.intman.2019.03.002

CITATIONS

READS

0

20

2 authors:

Farhan Ahmad

Edge Hill University

16 PUBLICATIONS 36 CITATIONS

SEE PROFILE

Some of the authors of this publication are also working on these related projects:

Project The Impact of Information Literacy in the Digital Workplace (DiWIL) View project

Project Factors Affecting E-Learning Acceptance Among Saudi Students View project 
False foe? When and how code switching practices can support knowledge sharing in multinational corporations

\section{Cite as}

Ahmad, F., \& Barner-Rasmussen, W. (2019). False foe? When and how code switching practices can support knowledge sharing in multinational corporations. Journal of International Management, https://doi.org/10.1016/j.intman.2019.03.002

Final version is available at https://doi.org/10.1016/j.intman.2019.03.002. 


\title{
False foe? When and how code switching practices can support knowledge sharing in multinational corporations
}

\begin{abstract}
The operating environment of multinational corporations (MNC) is multilingual, adding significant complexity to knowledge-sharing interactions between employees. In this paper, we explore how knowledge sharing in MNCs is influenced by code switching, or shifting between languages during interaction. Previous international business research has mostly described codeswitching as a behavior that has a negative impact on knowledge sharing by creating distrust and exclusion. Our case study of a major Finnish MNC from the perspective of the Faultine Theory shows that in situations where organizational norms and routines help limit the potential impacts of code switching on subgroup formation and inter-subgroup animosity, it can also aid knowledge sharing by (i) supporting the development and maintenance of key technical vocabulary, (ii) enhancing inclusion in knowledge-sharing interactions, and (iii) supporting knowledge contextualization processes. Thus, code switching is not necessarily just a form of linguistic interference, but it can also be intended - and often functions - as a strategic behavior that draws on multiple languages to build efficient and successful knowledge-sharing interactions.
\end{abstract}

Key terms; language diversity; code switching; knowledge sharing; corporate language; multinational organization; knowledge management

\section{Introduction}

Multinational corporations (MNCs) are multilingual almost by default (Barner-Rasmussen \& Björkman, 2007), and hence linguistic differences and boundaries between units abound, having a pervasive impact on the relationships between them (Björkman \& Piekkari, 2009; MarschanPiekkari, Welch \& Welch, 1999; Mäkelä, Kalla \& Piekkari, 2007). Indeed, the impact of language on the operations of MNCs has become acknowledged as a major issue in international business (IB) in recent years (see e.g., Brannen, Tietze \& Piekkari, 2014; Peltokorpi, 2017; Piekkari \& Tietze, 2011; Tenzer, Terjesen \& Harzing, 2017).

In terms of impact on day-to-day operations and MNC performance, what stands out as particularly important is the impact of such differences and boundaries on knowledge sharing between units and individuals in the MNC. Knowledge sharing has been considered crucial for the competitiveness and long-term viability of the MNC since the seminal contributions of Hedlund (1986), Bartlett and Ghoshal (1989) and Grant (1996). More recent research following in the footsteps of Marschan-Piekkari, Welch \& Welch (1999) has, in turn, firmly established the importance of language for knowledge sharing (e.g., Feely and Harzing, 2003; Klitmøller \& Lauring, 2013; Peltokorpi, 2015; Schomaker \& Zaheer, 2014; Welch and Welch, 2015). How language impacts knowledge sharing between units and individuals is thus established beyond doubt as a core topic of IB research.

In this paper, we focus on a particular aspect of language use, namely code switching, and explore how it influences knowledge sharing inside an MNC. Following Nunan and Carter (2001:275), we define code switching as the phenomenon of "switching from one language to another in the same 
discourse." As we indicate in our literature review, code switching has received extensive research interest in different subfields of linguistics, such as sociolinguistics, linguistic anthropology, and psycholinguistics, but has so far been studied relatively little from the perspective of languagesensitive IB research.

Furthermore, with regard to the limited extent that IB research has addressed code switching, it has mostly been described as a negative behavior that emphasizes and widens the gaps between individuals and units. Empirical accounts (e.g., Neeley, Hinds \& Cramton, 2012; Hinds, Neeley \& Cramton, 2014; Tenzer, Pudelko \& Harzing, 2014; Tenzer \& Pudelko, 2015; Wang et al., 2018) center on phenomena such as subgroups switching to their native language during a meeting held in another language, causing other parties present to experience feelings of exclusion or distrust, with repercussions on their willingness to share knowledge. Tenzer and Pudelko (2015) have recently pointed out that engaging in code-switching may be helpful for linguistically less skilled individuals, and that its effects can be moderated by astute managerial action. However, the dominant interpretation of code switching remains negative in their study also, as do most empirical examples of it.

We contribute to this discussion by expanding upon the notion that code switching in MNCs can also have positive effects (cf. Tenzer \& Pudelko, 2015), and by shedding light on the conditions under which this may be the case. Drawing on 22 interviews from an exploratory case study in a Finnish MNC, we argue that code switching is best approached as a contextually embedded language practice that is usually not negatively intended and certainly not always understood as such. It can be an efficient means to solve comprehension challenges during knowledge sharing between linguistically and culturally diverse MNC employees. Such a more nuanced understanding of code switching is starkly relevant to knowledge sharing in an operative environment characterized by increasing globalization. Globalization, while often accompanied by 'Englishization' (Dor, 2004), is also concomitant with increased workforce diversity both at home and abroad, thereby increasing the complexity of MNCs' linguistic setup. Hence, behind the veneer of corporate English, a growing number of languages is being drawn upon during daily work-related interactions in MNCs. This creates increasingly complex linguistic landscapes where code switching is likely to be both frequent and troublesome unless it is properly understood and managed. Developing a holistic understanding of code switching and its implications is thus an important challenge. Our findings indicate that when code switching is undertaken in a trusting environment and with management support, it can provide useful support for knowledge sharing. This is highly relevant for managers to better understand and harness code switching for positive organizational purposes. These takeaways have important implications for cross-border knowledge transfer, business and management training and international business communication.

The theoretical lens we apply to code switching is that of faultines (Lau \& Murnighan 1998, 2005), or the notion that in all groups, individual members have attributes which could potentially splinter the group up into subgroups. Common examples of such attributes in the literature are gender, nationality or, indeed, language. As we will explain in more detail later, the Faultline Theory offers a holistic perspective on the emergence of organizational subgroups that can integrate both previous findings on the negative impacts of code switching and the potential positive effects that we highlight here. Therefore, it constitutes a solid theoretical base for a study on this topic. 
In what follows, we first review relevant previous literature on knowledge sharing in MNCs with a focus on MNCs as multilingual organizations, code switching, and the Faultline Theory. We then introduce the methodology of our exploratory study, which builds on interviews with managers in the global network of a leading Finland-based MNC. Finally, we explicate our analysis and its results before closing with suggestions for future research and managerial implications of our study.

\section{Literature review}

\subsection{Knowledge sharing in MNCs}

Most knowledge-sharing activities in an organization can be characterized as either active or passive (Hansen, Nohria \& Tierney, 1999; Huysman \& De Wit, 2004). Employees can acquire knowledge from internal databases and documents that contain the knowledge of other employees, for example in the form of instructions on how to do something (Brown et al., 2013; Dalkir \& Liobowitz, 2011). This repository-based knowledge sharing is essentially passive because there is a lack of interactive dialogue or discussion between individuals (Ackerman, Pipek \& Wulf, 2003). On the other hand, active knowledge sharing, also known as interpersonal knowledge sharing, involves interactive exchange of task-related information, advice and expertise between employees to solve complex problems and develop new ideas (Huysman \& De Wit, 2004; Ipe, 2003; Wang $\&$ Noe, 2010). Interpersonal knowledge sharing is extremely dynamic due to the collaborative and participatory nature of the communication. According to Nonaka and Takeuchi (1995), it is this interactive nature of interpersonal knowledge sharing that makes it crucial for organizational success as it creates a rich dialogue in which exchange and creation of ideas happen concurrently.

Interpersonal knowledge sharing, just like any other interactive activity, depends on language to express experiences and develop discussions and shared understandings of topics of common interest. However, it is not only the availability but also the skillful use of language that matters for interpersonal knowledge sharing. According to Eppler (2007), knowledge-sharing interactions involve a myriad of didactic tricks and speech acts that are critical for communicating complex thoughts and ideas.

In the context of MNCs, knowledge sharing takes on additional importance as it is widely recognized that the ability of these companies to transfer knowledge across and within units in their far-reaching international networks constitutes one of their fundamental competitive advantages (Bartlett and Ghoshal, 1989; Gertsen \& Søderberg, 2012; Nadayama, 2018; Yamao et al., 2009). However, its degree of difficulty is also increased (Ambos \& Ambos, 2009). An important reason is the multilingual nature of most MNCs, highlighting the importance of language and the ability to share knowledge across language boundaries.

There is clear evidence that introducing a common corporate language (CCL) is not a comprehensive solution to this problem (see e.g., the recent literature review by Tenzer et al., 2017). CCL choices are politically and culturally loaded (Vaara et al., 2005). CCL skills vary across functions and hierarchical levels (Barner-Rasmussen and Aarnio, 2012) as well as employee demographic groups (Neeley, 2013), and many local market activities must be undertaken in local 
language(s) due to factors such as client demands and the need for local legitimacy (Brannen et al., 2014; Feely and Harzing, 2003; Marschan-Piekkari et al., 1999). MNCs thus face the dual challenge of being dependent on high-quality interunit connections while operating in a plethora of languages. The onus to respond to this challenge is on individual employees and teams who are forced to navigate language boundaries in the course of their day-to-day work (Marschan-Piekkari et al., 1999). This draws attention to how language is handled in microlevel knowledge-sharing interactions (Foss and Pedersen, 2002).

Research at these levels of analysis has uncovered significant variation between individuals with regard to both ability and propensity to bridge between different language groups (BarnerRasmussen et al., 2014; Mäkelä, 2007; Tenzer and Pudelko and Harzing, 2014; Tenzer and Pudelko, 2015), and has investigated different individual-level strategies for doing so. These strategies may include mechanical or human translation (Janssens, Lambert and Steyaert, 2004; Piekkari et al., 2013; Tietze, 2010), relying on interpreters (e.g., Ribeiro, 2007), using boundary objects such as drawings or blueprints (Sunaoshi, Kotabe and Murray, 2005) and different forms of mixing languages (Janssens and Steyaert, 2014; Lüdi, Höchle and Yanaprasart, 2013; Steyaert, Ostendorp and Gaibrois, 2011). Our focus here is on code switching as a commonly occurring and highly important form of such language mixing. In what follows, we first explain this concept and then review current research on its impacts in MNC contexts.

\subsection{Code switching}

Code switching as a topic has been studied meticulously in linguistics (Isurin, Winford \& Bot, 2009). The term code switching was first used in the 1950s, though its origin is largely unknown because of the interdisciplinary nature of the concept (Benson, 2001). According to Nilep (2006), around 1,800 articles had been published on the topic of code switching by the end of 2005. This number, which is certain to have grown significantly by today, clearly signals code switching as an important linguistic behavior.

It is important to note that, for linguists, a "code" in this context does not always mean a language. Any kind of system that two or more people employ for communication can be called a code, and therefore, it may refer to a dialect, vernacular, pidgin, creole, and so on (Wardaugh, 2010: 84). In the context of organizations, the organizational jargon or 'company speak' (Marschan-Piekkari et al., 1999) can also be a code. However, at present, a code in the context of code switching is widely accepted to represent a language. In line with this interpretation, we define code switching as the phenomenon of "switching from one language to another in the same discourse" (Nunan and Carter, 2001:275). The switch can be short-term, as when mixing languages by using words from different languages, or long-term, when a complete shift is made from one language to another (Schau et al., 2007).

Why do people switch between languages in interactions? Empirical evidence suggests a number of factors, such as language proficiency, interaction setting, group affiliation, topic and typological distance between languages, all of which can influence code switching (Bot et al., 2009). Nevertheless, language proficiency is thought to be the most important and natural trigger of code switching. It is quite rare that an individual has equal competency in multiple languages (Baker \& Jones, 1998). The imbalance in linguistic competencies can make an interlocutor oscillate between 
languages, particularly when the common language being used is not the first choice for interaction.

Code switching has negative connotations. It signals lack of competency in one or both languages, or even lack of intelligence (Dewaele \& Wei, 2014). As the shifting between languages can lead to conflict through identity marking, power exertion, or linguistic ostracism, code switching is generally thought to be a behavior best avoided. Nevertheless, modern linguistics, particularly sociolinguistics, has underlined plenty of positive aspects of code switching in terms of its role in communication. For example, it is used for speech accommodation to reduce linguistic distance between interlocutors (Rose, 2006). It can be helpful to underline a point, to amplify the message and to clarify what is said (Gumperz, 1982). It can perform a directive function in which conventional mode of address and standard greetings from a particular language are used to ensure a cooperative conversation structure (Appel \& Muysken, 2006). It can be used for stylistic effect when words or sentences from another language are used to create aesthetic effect or humor in the conversation (Ritchie \& Bhatia, 2006). In short, code switching has positive aspects, and it is more than simply an effort to compensate for linguistic deficiency. According to Bailey (2000), the role of code-switching is strategic in multilingual environments. It helps in attending to the sociolinguistic sensitivities and contextualization cues of interaction; hence, it enriches the interaction (Gardner-Chloros, 2009; Gumperz, 1982).

When code switching, individuals have shown strong capability to strike a balance between the potential communication loss and speech power that multiple languages can bring into a conversation (Myers-Scotton \& Bolonyai, 2001). Over the years, code switching has gained a reputation as a linguistic behavior that enhances continuity and impact of the speech in multilingual environments (Benson, 2001; Skiba, 1997). According to many linguists, code switching is evidence of advanced control where an individual "justifies his or her language choice to manage the communication demand" (Dewaele \& Wei, 2014:237; Genesee, 2003). Therefore, in multilingual environments, it is not surprising to observe code switching by individuals (Wardaugh, 2006).

\subsection{Code switching and knowledge sharing in MNCs}

Little is known about the relationship between code switching and knowledge sharing in the context of MNCs. Few IB studies devote their attention exclusively to code switching, but to the extent that this behavior is covered in this literature, its consequences are nearly exclusively portrayed in a critical light (Antonio, 1987; Brannen, 1994; Lauring, 2008), particularly for knowledge sharing between linguistically diverse employees (Harzing and Feely, 2008; Tange and Lauring, 2009). Studies focusing on language diversity on multilingual teams have observed it to be common (Harzing, Köster and Magner, 2011; Hinds et al., 2014; Lauring, 2008; Neely, Hinds and Cramton, 2012), and some recent empirical research (notably Tenzer and Pudelko, 2015) notes that it may also have positive effects. Nevertheless, the dominant interpretation of code switching, as well as most empirical examples of it in the IB literature, is as a divisive practice that excludes potential knowledge-sharing partners from the discussion.

Hinds et al. (2014) conducted a study on the impact of language diversity on the work of international software development teams using English as the common language of interaction. 
They found that a lack of competency in the common corporate language was a common cause for code switching. In extreme cases, knowledge-sharing interaction turned completely to non-English language use - that is, long-term code switching - that was strongly objected by team members. Sometimes it triggered as strong responses as leaving the meeting and filing an official complaint with the company management. The common feeling was that it is difficult to be a productive team member when one cannot understand the switched language and consequently cannot contribute with personal insights and ideas.

Similarly, Aichhorn and Puck (2017a) noted that the members of an international team found code switching a barrier to fruitful dialogue. Particularly in online meetings, team members tended to switch to their native language to converse with other speakers of the same language, which, according to other respondents, left them excluded and puzzled about what had been discussed. It created blank spots in knowledge sharing (Ahmad and Widén, 2018), that is, interlocutors were able to grab only bits and pieces of a discussion. Code switching not only impaired face-to-face discussion but also negatively influenced information sharing through written media such as email. Email threads in multiple languages were seen as a hindrance to quick and effective dissemination of critical information (Aichhorn and Puck, 2017a:1).

Detrimental effects of code switching on trust and consequently on knowledge sharing have received particular emphasis in prior IB research. According to Harzing and Feely (2008:55; see also Harzing et al., 2011), "a switching of codes just when it was getting interesting smacks of conspiracy and double-dealing", and consequently leads to trust issues. Code switching as a barrier to trust formation during knowledge-sharing interaction was observed by Tenzer et al. (2014:524), who conducted a study on multilingual teams of three multinational companies and noted that most team members perceived code switching during meetings as undesirable. It was characterized as "annoying and unfair" and created feelings of exclusion and suspicion. Most importantly, team members suspected malevolent intentions that eroded the trust between team members, consequently influencing knowledge sharing negatively.

Sociolinguists argue that focusing on the negative aspects of code switching reflects an inclination toward dual monolingualism or linguistic purism (Wei and $\mathrm{Wu}, 2009$ ), denoting the view that a bilingual person has two different language competencies, like those possessed by two monolingual persons, which should be used autonomously (Grosjean, 1989). From this perspective, code switching is considered as careless language use and represents 'deviant behavior' that defies the principle of good interaction, that is, one language at a time (Weinreich, 1953). Modern sociolinguistics rejects the idea of dual monolingualism and proposes a holistic view of multilingualism in which knowledge of multiple languages forms a single linguistic repertoire of individuals (García and Wei, 2013; Jørgensen, 2008). Code switching is seen as skillful linguistic behavior that draws on proficiency in multiple languages and helps to promote efficient communication. This dimension is by and large absent from extant IB research.

\subsection{Faultline Theory}

The Faultline Theory (Lau \& Murnighan, 1998, 2005) holds that member attributes have the potential to splinter a group up into subgroups in a process where barriers ('faultlines') tend to form between subgroups along member attributes, thereby accentuating subgroup salience, heightening conflict and reducing trust. 
Early iterations of the theory focused on faultline formation along demographic characteristics, such as race, gender or nationality. However, Lau and Murnighan (1998) pointed out that contextual factors such as organizational culture may accentuate faultline salience. Subsequent empirical research has argued that faultlines can be based on many different attributes (e.g., Lau and Murnighan, 2005), including non-demographic ones such as geography (cf. the notion of location-based faultlines, Polzer, Crisp, Järvenpää \& Kim, 2006), and linguistic fluency differences (which may activate pre-existing faultlines in teams that are involved in power struggles; see Hinds, Neeley \& Cramton, 2014).

Particularly relevant to our discussion is the argument for a cognitive perspective on faultlines (e.g. Homan, van Knippenberg, Kleef \& de Dreu, 2007; Jehn, Zanutto and Thatcher, 2009; Jehn and Bezrukova, 2010), which emphasizes what group members themselves perceive as faultlines and when and why they are triggered. Bezrukova and colleagues (2009: 47) argue that "...active group faultlines [only] exist when the members perceive and behave as if there are two separate, different (and potentially even opposed) subgroups." A similar point has also been made in sociolinguistics: Roberts (2007) has argued that cultural or ethnic background is a significant dimension of crosscultural or -lingual encounters only if made relevant in the interaction.

Against the background of these arguments, a faultline perspective on code switching in MNCs firstly suggests that previous observations of mainly negative effects may stem from empirical contexts characterized by active faultlines (see e.g., Hinds and colleagues, 2014). Secondly, the cognitive perspective on faultlines reminds us that group members do not necessarily perceive linguistic fluency differences or the use of different languages as a marker of separate subgroups, let alone conflicting ones. This draws our attention to the explanatory factors behind situations when code switching is not perceived in negative terms. Lau and Murnighan's (1998) mention of organizational culture offers a clue to contexts where and why this might occur.

Based on the previous discussion, we argue that the role of code switching in knowledge-sharing interaction in MNCs is yet to be fully understood, particularly regarding its positive aspects. Whereas previous research has advanced our understanding of the problems posed by code switching in knowledge sharing, it has clearly neglected how code switching as a strategic linguistic behavior can have positive implications for knowledge sharing. Therefore, this study adopts the holistic view of multilingualism and investigates whether and how code switching can support knowledge sharing in MNCs.

\section{Methodology}

Given the limited prior research on code switching in MNC knowledge sharing and particularly on its potentially positive aspects, a qualitative exploratory study was considered the most appropriate approach. According to Eisenhardt (1989) and Yin (2006), qualitative research design is suitable for addressing "how" questions, such as the one being investigated in this study. A case study was conducted in a large Finnish MNC, hereinafter Gamma, a big player in the energy industries. It operates in some 70 countries around the world, has around 15,000 employees and annual revenues of more than 4 billion U.S. dollars (2016). A summary of the company's background is provided below. 


\subsection{Case company description}

Gamma began as a regional Finnish actor but expanded overseas already in the early $19^{\text {th }}$ century. It experienced rapid market growth in the 1980s and early 1990s through strategic acquisitions in e.g. the UK, Sweden, South Africa, Germany and the USA. Since the early 2000s, Gamma has made no major structural changes but has focused on internal development, e.g. integration of acquisitions, alignment of major business units' goals and strategies and homegrown product innovation.

Gamma has been exposed to language diversity throughout its history. Its roots are in a bilingual country (the official languages of Finland are Finnish and Swedish), and its top management and board have been dominated by Swedish-speakers, a linguistic minority in Finland. Gamma internationalized early on, which entailed a high degree of internal language diversity even before the start of the modern era of business globalization. English was adopted as Gamma's common corporate language (CCL) in the early 1990s. It was seen as a natural move, as apparent in the comment of a Norwegian interviewee who stated, "the nature of our products and service has always been very English [language] - international operations and customers." The corporate language policy is flexible, stating that English is the CCL, yet circumstances permitting, employees are allowed to use other languages. Alongside English, some other languages, called 'big languages' in the company, are highly valued. These languages (German, Swedish, Chinese, and Italian) are mainly those that entered Gamma's linguascape (Steyaert et al. 2011) through foreign acquisitions and/or represent major business markets. Fluency in these languages is seen as an asset. Recognition of the 'big languages', in addition to English, underlines Gamma's pluralistic stance towards languages.

Since adopting a CCL, Gamma has made many formal and informal initiatives to counter potential language-related challenges. Officially, the organization arranges language courses and intercultural communication training programs. Although not directly designed to counter language-related challenges, expatriate assignments, which are very common in Gamma, play a significant role in exposing employees to language diversity. Gamma's corporate communication department is very active in supporting language diversity. To avoid linguistic ostracism, it maintains an internal newsletter, magazines and social media in different languages. Simultaneously, it encourages employees to use 'English without fear' to decrease non-native language use anxiety. Overall Gamma's long exposure to language diversity has promoted a culture of tolerance and permissive attitude to multilingual behavior.

In sum, a high degree of organizational multilingualism is evident in Gamma not only across subsidiaries, which operate in different countries and therefore use different languages, but also within subsidiaries. For example, 40 percent of the workforce in the company's Finnish subsidiary is composed of non-Finns. Moreover, expatriate movement and international recruitments are quite common. Most of the work is carried out on teams that are often composed of individuals with diverse cultural and linguistic backgrounds. Due to the high level of multilingualism in its operations and workforce, Gamma was a suitable candidate for investigating the impact of code switching on knowledge sharing. 
As a multinational organization, Gamma has a range of departments and hence represents a diverse stock of expertise. The presence of diverse functions, such as R\&D, marketing, legal affairs and production, means knowledge existed in its various forms representing different professions and types such as tacit and explicit. Due to knowledge intensive products, Gamma relies heavily on its tacit knowledge for innovations in all of its operations ranging from marketing and human resources to engineering. Simultaneously, it has invested efforts in knowledge documentation, particularly in the standard procedures and problem solutions in production and repairing. Therefore, knowledge in this case study does not focus on any specific type. Instead, it involves all kinds of know-how and expertise critical in organizational operations, such as marketing strategy development, product and service innovation and supply change management.

\subsection{Respondents}

For the purpose of this study, a theoretical sampling approach was adapted (Corbin \& Strauss, 2008) whereby insights generated from the data guide the data collection process. An effort was made to select candidates who could provide relevant and rich insights into knowledge sharing in relation to organizational multilingualism. Consequently, the candidates selected for interviews were those who regularly engaged in knowledge-sharing activities such as meetings and project discussions with linguistically diverse employees. These criteria were discussed with the MNC management, who helped in identifying 16 suitable candidates from six subsidiaries. In addition, a snowball sampling technique was used (Atkinson and Flint, 2001). Interviewees were asked to disclose the names of individuals who could provide additional useful insights into the topic of the interview. We used this technique during the interviews when the interviewees mentioned certain individuals. For example, a native Finnish speaker interviewee brought up the name of a native Swedish speaker who often faced code switching situations in team meetings, whereas the native Swedish speaker herself was often hesitant to code switch. In such cases, we requested the interviewee's referral and the support of the company's management to recruit potential interviewees as they could provide potential divergent views on code switching. Although sourcing participants via the snowball technique is useful for recruiting respondents who are most knowledgeable about the topic, it may also introduce some bias due to network effect, which is its limitation (Robinson, 2014). Nevertheless, it is less likely to be the case in our study as our data collection was guided by the emerging theory and only six interviewees were recruited in this way.

Overall, a total of 22 interviews were conducted with employees from seven different subsidiaries. To enhance maximum variability and unit triangulation, interviewees with diverse characteristics were selected, i.e. age, native language, English language competency, hierarchical position, professional background and company tenure. These considerations were also taken into account for the respondents identified through snowball sampling. Table 1 shows a detailed overview of the respondents' profiles.

\subsection{Data collection}

This study forms part of a larger research project investigating knowledge sharing in multilingual organizations from different perspectives. In this project, we have used surveys and interviews. A survey was also conducted in the case organization used in this study. The survey contained questions on the language diversity related topics that are not directly relevant to this study; 
however, it contributed to the development of our general understanding regarding language atmosphere in the organization. For example, in the survey, we found that employees in the case organization had very positive attitudes toward the corporate language, and they had good connections with linguistically diverse employees in their personal knowledge networks.

Table 1. Respondents' profiles.

\begin{tabular}{|c|c|c|c|c|c|c|c|}
\hline Respondent & Gender & Location & Function & $\begin{array}{l}\text { Hierarchal } \\
\text { level }\end{array}$ & $\begin{array}{l}\text { Tenure } \\
\text { (years) }\end{array}$ & \begin{tabular}{|l|} 
Native \\
language
\end{tabular} & $\begin{array}{l}\text { Foreign language } \\
\text { skills }\end{array}$ \\
\hline 1 & $M$ & \begin{tabular}{|l|} 
Finland - \\
HQ \\
\end{tabular} & $\begin{array}{l}\text { Business } \\
\text { development }\end{array}$ & $\begin{array}{l}\text { Level } 2 \\
\text { manager }\end{array}$ & 6 & Finnish & English \\
\hline 2 & $\mathrm{~F}$ & $\begin{array}{l}\text { Finland - } \\
\text { Subsidiary }\end{array}$ & Construction & $\begin{array}{l}\text { Level } 1 \\
\text { manager }\end{array}$ & 3 & Finnish & $\begin{array}{l}\text { Swedish, English, } \\
\text { Chinese }\end{array}$ \\
\hline 3 & $\mathrm{M}$ & Abu Dhabi & $\begin{array}{l}\text { Business } \\
\text { development }\end{array}$ & $\begin{array}{l}\text { Level } 2 \\
\text { manager }\end{array}$ & 22 & Arabic & $\begin{array}{l}\text { English, French, } \\
\text { Russian, Finnish }\end{array}$ \\
\hline 4 & $\mathrm{M}$ & Panama & Sales & $\begin{array}{l}\text { Level } 1 \\
\text { manager }\end{array}$ & 2 & Spanish & $\begin{array}{l}\text { English, Spanish, } \\
\text { Russian, German }\end{array}$ \\
\hline 5 & $F$ & $\begin{array}{l}\text { Finland - } \\
\text { Subsidiary }\end{array}$ & Marketing & $\begin{array}{l}\text { Level } 2 \\
\text { manager }\end{array}$ & 16 & Swedish & English, Finnish \\
\hline 6 & $\mathrm{~F}$ & $\begin{array}{l}\text { Finland - } \\
\text { HQ }\end{array}$ & Administration & $\begin{array}{l}\text { Level } 1 \\
\text { manager }\end{array}$ & 8 & Finnish & English, Swedish \\
\hline 7 & $F$ & Italy & Sales & $\begin{array}{l}\text { Level } 2 \\
\text { manager }\end{array}$ & 16 & Italian & $\begin{array}{l}\text { English, Russian, } \\
\text { French }\end{array}$ \\
\hline 8 & $F$ & Kenya & Procurement & $\begin{array}{l}\text { Level } 1 \\
\text { manager }\end{array}$ & 3 & Swahili & English \\
\hline 9 & $M$ & $\begin{array}{l}\text { Finland - } \\
\text { Subsidiary }\end{array}$ & Procurement & $\begin{array}{l}\text { Level } 2 \\
\text { manager }\end{array}$ & 17 & Finnish & English, Swedish \\
\hline 10 & $F$ & $\begin{array}{l}\text { Finland - } \\
\text { Subsidiary }\end{array}$ & Marketing & $\begin{array}{l}\text { Level } 2 \\
\text { manager }\end{array}$ & 7 & Finnish & $\begin{array}{l}\text { English, Swedish, } \\
\text { German }\end{array}$ \\
\hline 11 & $M$ & Germany & Construction & $\begin{array}{l}\text { Level } 1 \\
\text { manager }\end{array}$ & 7 & German & English \\
\hline 12 & $F$ & $\begin{array}{l}\text { Finland - } \\
\text { Subsidiary }\end{array}$ & Administration & $\begin{array}{l}\text { Level 1 } \\
\text { manager }\end{array}$ & 5 & Finnish & $\begin{array}{l}\text { English, Italian, } \\
\text { French, Spanish, } \\
\text { Russian }\end{array}$ \\
\hline 13 & $F$ & Italy & Administration & $\begin{array}{l}\text { Level } 1 \\
\text { manager }\end{array}$ & 10 & Finnish & $\begin{array}{l}\text { English, Italian, } \\
\text { Spanish }\end{array}$ \\
\hline 14 & $F$ & $\begin{array}{l}\text { Puerto } \\
\text { Rico }\end{array}$ & Procurement & $\begin{array}{l}\text { Level } 1 \\
\text { manager }\end{array}$ & 15 & Spanish & English \\
\hline 15 & M & Norway & Automation & \begin{tabular}{|l} 
Level 1 \\
manager
\end{tabular} & 7 & Norwegian & English, German \\
\hline 16 & M & Norway & Ship design & $\begin{array}{l}\text { Level } 1 \\
\text { manager }\end{array}$ & 4 & Spanish & English \\
\hline 17 & $M$ & $\begin{array}{l}\text { Finland - } \\
\text { Subsidiary }\end{array}$ & Procurement & $\begin{array}{l}\text { Level } 1 \\
\text { manager }\end{array}$ & 4 & Finnish & English, German \\
\hline 18 & $M$ & $\begin{array}{l}\text { Finland - } \\
\text { HQ }\end{array}$ & Communication & $\begin{array}{l}\text { Level } 2 \\
\text { manager }\end{array}$ & 7 & Finnish & English \\
\hline 19 & $F$ & $\begin{array}{l}\text { Finland - } \\
\text { HQ }\end{array}$ & Communication & $\begin{array}{l}\text { Level } 1 \\
\text { manager }\end{array}$ & 10 & Finnish & English \\
\hline 20 & $M$ & Italy & Sales & $\begin{array}{l}\text { Level } 1 \\
\text { manager }\end{array}$ & 3 & Italian & English \\
\hline 21 & $F$ & Panama & Legal & $\begin{array}{l}\text { Level } 2 \\
\text { manager }\end{array}$ & 3 & Spanish & English \\
\hline 22 & $M$ & Spain & Engine repairing & $\begin{array}{l}\text { Level } 1 \\
\text { manager }\end{array}$ & 3 & Spanish & English \\
\hline
\end{tabular}


In the project, the initial focus was on the impact of code switching on knowledge networking. However, after a few interviews it became clear that code switching was perceived as a useful linguistic behavior particularly for interpersonal knowledge-sharing interactions. This prompted us to focus explicitly on code switching and knowledge-sharing interactions during the interviews. The insight that code switching is not solely a negative behavior thus grew inductively out of the data collection and analysis process.

In this study, the primary source of data consisted of semi-structured interviews. Depending on the aim of the study, different methods and techniques have been used to study code switching. These data collection techniques include recording speech, interviews, observations, surveys and experimental elicitation in laboratory settings (Stell \& Kofi, 2015). Recording speech and ethnographic observations are used when the focus is specifically on switches in sentences (Gullberg et al., 2009). Such studies tend to investigate the nature of the linguistic constraints governing code switching and its processing, or the relationship of language with social constructs such as power, identity, and prestige; code switching is then seen as affording insights into such relationships (Bullock \& Toribio, 2009).

We were not concerned with any of these matters. Instead, we wanted to tap into respondents' views about code switching during knowledge-sharing interactions. For this purpose, interviews were suitable as they can provide "thick detailed descriptions" while preserving the actual meanings that respondents ascribe to their code-switching practices (Gephart, 2004:455). To study code switching as a general linguistic practice, many previous studies have used interviews and even surveys (e.g., Balam \& Pérez, 2017; Dewaele \& Wei, 2014). Observation could have provided useful supplemental data, but we were not permitted to carry out observations. This limitation was offset to some extent by our collection of stories about language diversity and knowledge sharing. At the end of each interview, we asked the interviewees to report in detail stories or critical incidents of both successful and failed knowledge-sharing episodes in English. Overall, we collected 19 stories that were also coded.

An interview guide was developed containing open-ended questions aimed at generating open and exploratory discussions. Before data collection, the interview questions were discussed with a senior researcher and later with the management in the target organization to adjust the relevance of the questions to the working style of the organization. Moreover, a pilot interview was conducted with an executive who had more than 10 years of working experience in Microsoft and had worked in different countries and multilingual teams. The pilot resulted in some adjustments to the interview questions.

The interview guide consisted of three parts. The first part contained questions on the respondents' background and work responsibilities. The second part contained questions pertaining to various types of knowledge-sharing activities to understand the general knowledge-sharing style and behavior of the respondent. Interpersonal knowledge sharing was contextualized in the form of collaborative discussion such as problem solving, sharing of expertise and developmental discussions, such as when creating new services and products. The third part contained questions pertaining to the use of multiple languages during knowledge-sharing interactions. 
Building on the previous discussion, respondents were asked to share their experiences regarding the use of CCL and code switching, a sample question being, "What language(s) do you use while solving a complex problem with your colleagues?" Initially, respondents were given the opportunity to bring up the code-switching practices themselves and most of them did, but if they did not, a direct question was posed, "Has it happened that you or someone else shifts languages while discussing an engine vibration issue?" Respondents were encouraged to share examples and describe specific scenarios with the assurance of anonymity. As the interviews progressed, new questions focusing on emerging themes were added.

The interviews were conducted in English for several reasons. First, it was Gamma's CCL, which made it easier to talk about the company's business and routines in that language and gave us insights into respondents' CCL proficiency that we would not have gained by interviewing them in their native languages. Second, we avoided the use of interpreters who, as Usunier (1998:2) points out, can produce "artificiality and an absence of tempo." Third, the reporting language of our research is English, so interviewing in English avoids the "problematic of translation, reduces noise and provides greater convenience in the analyses" (Welch and Piekkari, 2006:427). Fourth, the broad range of native languages among the respondents meant that we could not have interviewed all of them in their respective native languages. Hence, we judged that conducting all interviews in English would give us a fairer and more balanced view than allowing some respondents to speak in their native language while asking others to speak English.

We acknowledge that not interviewing participants in their native language may in principle influence their answers. However, in our case, in addition to the advantages already mentioned, this potential drawback is mitigated by the fact that all the interviewees were in managerial positions and hence had reasonably good CCL proficiency. At the same time, this last point constitutes a limitation in terms of the representativity of this study's findings, given that studies (e.g., Barner-Rasmussen and Aarnio, 2011) have shown language skills to vary significantly across hierarchical levels and functions. We return to these issues in the discussion of our findings and suggestions for future research.

Seven interviews were conducted face-to-face and the rest were conducted as audio/video calls through Skype for Business. Online interviewing has a number of very significant advantages: it decreases research costs in terms of both time and money, enhances the opportunity to interview distant and diverse respondents and allows reflective responses regarding sensitive issues (Deakin \& Wakefield, 2014). Without online interviewing, the geographic scope of this study would have been significantly restricted. Also, Skype has been used extensively for meetings in this particular $\mathrm{MNC}$, meaning that all of our interviewees were very comfortable with using this medium of communication. Even some of the interviewees in Finland, who were offered the possibility of a face-to-face interview, chose to be interviewed online as they found it more convenient. All the interviews were audio-recorded and transcribed verbatim. The average interview time was $58 \mathrm{~min}$, the shortest was $28 \mathrm{~min}$, and the longest was $93 \mathrm{~min}$.

\subsection{Data analysis}

The data collection and analysis involved an iterative process, meaning that analysis began while the interviews were still ongoing (Eisenhardt, 1989; Piekkari et al., 2013) and insights from the 
initial analysis could be incorporated into later interviews, allowing a deeper analysis that could not otherwise have been possible. All interview transcripts were imported into NVivo 11 for systematic analysis. First, all the transcripts were read thoroughly to get an in-depth understanding of the respondents' knowledge-sharing interactions and code-switching behavior. We also paid attention to and documented tensions between units, groups and individuals as indicators of possible faultlines in the case company. Then, as suggested by Lofland and Lofland (1994), a twostep analytic coding procedure was adopted. In the first stage, the interviews were coded line by line. Codes were not predefined or imposed; rather, they emerged from the data. In the second stage, codes were sorted and categorized according to the research question. At this stage, the different codes were juxtaposed and summarized resulting in abstract categories (such as code switching for inclusion). Moreover, similarly coded segments from the different interviews were compared and further refined into emerging themes. As the analysis progressed, three themes crystallized: support to technical vocabulary, inclusion in knowledge sharing and help in knowledge contextualization. Table 2 depicts an example of the coding and emerging themes. This analytical phase confirmed that the interpersonal relationships captured in the data were characterized by an absence of strong tensions, bolstering the initial impression from the survey and company history that active faultlines were not a prevalent feature of Gamma.

Table 2. Example of coding.

\begin{tabular}{|c|c|c|}
\hline Theme & Codes & Quotes \\
\hline \multirow{3}{*}{ 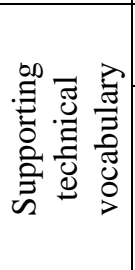 } & To create terms & $\begin{array}{l}\text { I design new processes and words (their names) so to say. You really have to be very } \\
\text { strict (stick to English).... because it is important that everyone understands. }\end{array}$ \\
\hline & \multirow{2}{*}{$\begin{array}{l}\text { To maintain } \\
\text { vocabulary }\end{array}$} & $\begin{array}{l}\text { In technical discussions, there are words that are used in English only, not translated, } \\
\text { so that then everybody knows what it is. Translation can bring complications. }\end{array}$ \\
\hline & & $\begin{array}{l}\text { Particularly technical words, we very often add English words in our Finnish } \\
\text { discussions. For technical vocabulary, like engine parts, we use English words only. }\end{array}$ \\
\hline \multirow{4}{*}{ 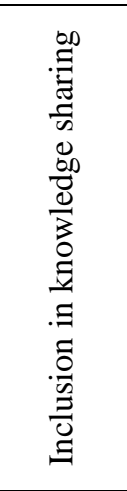 } & \multirow{2}{*}{$\begin{array}{l}\text { To get help } \\
\text { from others }\end{array}$} & $\begin{array}{l}\text { In our team meeting - sometimes they (Swedes) can quickly exchange some } \\
\text { thoughts in Swedish between themselves - if you are not able to explain in English, } \\
\text { it helps the discussion. }\end{array}$ \\
\hline & & $\begin{array}{l}\text { In marketing discussions, she says the words in her language. It also happens that } \\
\text { she asks from the colleagues the correct word in Finnish. }\end{array}$ \\
\hline & \multirow{2}{*}{$\begin{array}{l}\text { To } \\
\text { accommodate } \\
\text { switching }\end{array}$} & $\begin{array}{l}\text { When in a meeting she wants to present or discuss something critical, she shifts to } \\
\text { English, as it is easier for her. Then we also switch to English and get good } \\
\text { discussion. }\end{array}$ \\
\hline & & $\begin{array}{l}\text { Code switching happens all the time in project meetings. In a way, it is good because } \\
\text { people can share information and thoughts easily. For me it is fine. It is a matter of } \\
\text { perception. You can take it as a problem, or you can just accept that this is how the } \\
\text { world is. }\end{array}$ \\
\hline \multirow{3}{*}{ 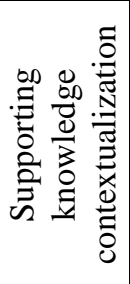 } & $\begin{array}{l}\text { Word search } \\
\text { problem }\end{array}$ & $\begin{array}{l}\text { In our English meetings, a person may forget the word because he is not good in } \\
\text { English. He might explain or discuss it in Spanish - it helps to focus the discussion. }\end{array}$ \\
\hline & \multirow{2}{*}{$\begin{array}{l}\text { Message } \\
\text { repetition }\end{array}$} & $\begin{array}{l}\text { Like instructions to use SAP -you use it to do many things. When you explain it in } \\
\text { English, they may not get all of it, try another language, it does not hurt. }\end{array}$ \\
\hline & & $\begin{array}{l}\text { If they do not understand my points (in German), then again, I have to shift (back) to } \\
\text { English to repeat those parts. }\end{array}$ \\
\hline
\end{tabular}

During the process of developing themes, we shifted back and forth between data and literature as per qualitative research tradition (Hardy \& Bryman, 2004; Patton, 2002). This was useful for conceptually fine-tuning the themes. For example, literature on the collaborative nature of 
knowledge sharing, including the concept of knowledge responsibilities and transactive memory, was helpful in building an understanding of how code switching can eradicate languagedeficiency-based exclusion during knowledge-sharing interaction. A number of memos were created during the interviews, immediately after the interviews and during coding. Memos were meant to jot down initial ideas, potential links emerging in the moment and for structuring thoughts (Corbin \& Strauss, 2008; Yin, 2006).

To further enhance the robustness of the study, we utilized triangulation (Creswell, 2007). We analyzed convergence across different sources of data, for example by comparing interview accounts to descriptions in the notes and stories, and by comparing findings across interviewees (Milosevic et al., 2015; Søderberg, 2015; Yin, 2006). A systematic comparison of emerging themes and patterns was made by treating different geographical regions as cases. This was a useful approach for enriching data analysis because the organization is a network of subsidiaries with very limited control by headquarters. This was clearly stated by organizational management and many of the interviewees. This means that, although Gamma is a single organization, the subsidiaries operate as standalone organizations with their own culture and working style. Moreover, findings were also compared across respondents from different age groups, hierarchies, and tenures (Ahmad, 2017). Such within-case analysis helps to find variations and discrepancies in emerging findings. The focus of the analysis was not only on finding converging patterns but also any disconfirming and conflicting perspectives and evidence (Piekkari et al., 2015).

The findings of this study, and how they emerged, were thoroughly discussed with the researchers who were a part of the project since the beginning. Moreover, findings were shared with selected respondents who confirmed that the identified themes made sense and reflected their experiences (Milosevic et al., 2015). The entire inductive research process resulted in the findings presented in the following section.

\section{Findings}

The analysis of the interview data focused on code switching in the context of knowledge sharing situations in Gamma, on the norms of language use that appeared to govern these situations and on how these norms appeared to be practiced in terms of routines. Our results indicate that these situations could be grouped into three broad categories: i) development and maintenance of a shared technical vocabulary, ii) enhancement of inclusion in knowledge sharing, and iii) support of knowledge contextualization processes. Each category is underpinned by norms colored by a positive attitude to multilingualism, yet - and importantly - also checked by strong norms and routines aimed to guarantee the inclusion of all relevant participants and maintain a common core vocabulary in English. With regard to faultlines, we found few expressions of tension based on either demographic or cognitive subgroups. Our interpretation is that this was indeed related to Gamma's inclusive corporate culture, as manifested in these same norms and routines and shaped by the company's history and decentralized structure, permitting code switching to take place in a trustful climate. The three categories are described below. 


\subsection{Supporting technical vocabulary}

Technical vocabulary refers to the commonly used terms, concepts, metaphors, names of the internal processes in an organization, products and functions (Welch et al., 2005). Such names and terms designate particular concepts and act as knowledge objects, that is, they are the embodiment of skills and reflection of the organizational ways of working (Nonaka \& Takeuchi, 1995). Technical vocabulary helps to decipher problems during knowledge-sharing interactions as it reduces ambiguity through processes of regularization, standardization and de-contextualization (Sager et al., 1980). For example, a group of engineers working on a faulty engine will build their understanding of the situation utilizing predefined terms and names of the potential diagnostic procedures designed in the organization.

The analysis of the data indicates that code switching during knowledge-sharing interactions helps to maintain technical vocabulary. According to the respondents, they are very flexible in terms of language selection for knowledge-sharing interactions. They use the common corporate language only when the team has a member from a linguistically different background. However, many teams are composed of individuals who have similar linguistic backgrounds or a mutually intelligible language such as Swedish for Finns and Norwegians. Therefore, the use of noncorporate language for knowledge-sharing interaction was common and also allowed by the MNC. However, our data reveal that the knowledge sharing participants switched continuously to the CCL for technical vocabulary. A Spanish employee stated, "When we are discussing a customer's problem or developing a new way of working, we use Spanish, but we stick to standard vocabulary in English." She continues,

"Our catalogues, spare parts and operational systems are named in English. When we talk about these, we use the words in English and we do not translate it into Spanish," (Respondent 14).

Similarly, a design specialist whose knowledge-sharing interactions involved issues regarding systems development with engineers said, "I work a lot with engineers, so then some of the technical terms are used in English. It is easier to use just the English terms that are familiar to most of us. We might talk in Finnish and use the technical terms in English." (Respondent 12)

Previous research (e.g. Vaara, Piekkari, Tienari \& Säntti, 2005) has found that one of the functions of language is to project professional competence, and prior research suggests that code-switching may be one way to achieve this (Goldstein, 1997). At Gamma, however, although noncorporate languages are commonly used during knowledge-sharing interactions, the strong adherence to technical vocabulary in English appears to be driven primarily by pragmatic reasons. Respondents see English terms and metaphors as representations of what is already known to them and, therefore, helpful in conceptualizing their problems and developing new solutions and ideas. In a common understanding prevalent among employees, they do not want to compromise the understanding of these terms by using them in other languages; hence, they code-switch to English. For example, a Puerto Rican purchaser, whose department works in collaboration with Dominican Republican colleagues, mentions that they mostly have discussion in Spanish but it always involves code switching. A few weeks ago, they had to redefine the purchasing protocol to make procurement of parts more efficient. This discussion, which focused on defining new procedures, was carried out in Spanish but involved a great deal of code switching to utilize established 
vocabulary, such as stage codes that refer to different episodes of an order's lifecycle. Consequently, code switching into English potentiated the knowledge sharing and creation process.

Not switching to English while using technical vocabulary could be detrimental to the employees' knowledge-sharing interaction. Efficient knowledge-sharing interaction requires the use of previously established terms that lessen the need for unnecessary explanations and act as shorthand for much broader, complex concepts (Aichhorn \& Puck, 2017). According to the participants, translated technical vocabulary could confuse them because translation could distort meanings, as stated by Respondent 9, "If suddenly in a discussion someone uses the term in Finnish, many people might be lost, what it is, what he is talking about, I have never heard the term, although it might be the same term but just in Finnish."

Code switching not only helps to maintain technical vocabulary but also to create such vocabulary. Gamma employees, regardless of the language used for knowledge-sharing interaction, always used English for creating the metaphors, analogies, abbreviations and names of problems and processes. One of the respondents explained that an important part of their problem-solving discussions is naming the problem and finding a solution for it. Both should be done in English. In the short-term, a new team member could join in or people from other units become involved, and they should be able to comprehend the vocabulary. In the long term, a different team could experience the same problem and benefit from the first team's experience. This type of situation would not be as straightforward if the vocabulary had been developed in a noncorporate language that could create knowledge transformation issues. Besides, corporate language policy dictates that all terms and terminologies referring to new processes and procedures should be in English. The organization frequently publishes an encyclopedia containing technical vocabulary developed within the organization. This publication is part of the organization's strategy to influence and contribute to the development of the industry by sharing its know-how and experience. This was also the reason why the organization strongly encouraged its employees to use English for building knowledge vocabulary. Consequently, even though discussions about problems and solutions are carried out in a language other than the corporate language, the terminology is always in English.

Although some employees switch codes during knowledge-sharing interactions with the aim to maintain and create technical vocabulary in English, others do it because they have no other choice. Many employees mentioned that they have learned the technical vocabulary in English, and they do not know alternative words for it in other languages.

"I have learned those things during my work, and I have learned those things in English. I have learned what "business white paper" [a report that outlines a solution based on Gamma's new technology addressed to a potential or existing customer's problem, such as energy consumption and exhaust gas emissions] is, for example. I didn't know what it is. I didn't know what that was before I came here. When you get to know the topics, terms, and concepts and the stuff we do here in English, you find it easier to use English [for them]." (Respondent 10)

Overall, it is very clear from the interviews that code switching in knowledge-sharing interactions is a common behavior. For some employees, there is no choice but to switch if they want to utilize technical vocabulary. Nevertheless, for others, it is a strategic behavior that helps them to create 
and maintain the technical vocabulary when they use a non-corporate language for knowledgesharing interactions. Moreover, it shows that employees possess a common understanding of language rules that provide a common frame of reference for inferring intentions and deciphering the meaning of code switching during knowledge sharing interactions. This enables trustful knowledge sharing interactions as there is no uncertainty among participants about the core technical issues under discussion. In this way, code switching to the CCL during knowledgesharing interactions also limits the negative repercussions of using a non-corporate language, which could mean loss of standard language and internal organizational vocabulary. Our findings suggest that, at Gamma, this is a strong norm that provides a perspective to code switching practices and helps guarantee the integrity of the company's knowledge base. Moreover, drawing upon this norm is not related to any active faultlines in the sense that those who switch codes would be regarded as deviant; on the contrary, code switching is part of the accepted behavior in the company and thus signals belonging in the context of this professional community, further helping participants trust each other.

\subsection{Inclusion in knowledge sharing}

Organizations bring together individuals with diverse backgrounds, for example, in the form of teams so that they can share their individual specialized knowledge for solving complex problems and developing innovations. According to Chen et al. (2013), every knowledge-sharing participant has knowledge responsibilities; when a team engages in knowledge work, knowledge-sharing participants should contribute fully by providing insights based on their expertise. If a knowledgesharing participant, for any reason, finds her ability to participate constrained, she will not be able to fulfill her knowledge responsibilities. This leads to exclusion of the person's subjective opinions and insights. Knowledge-sharing interactions that are not inclusive can result in a failed knowledge exchange and suboptimal solutions or decisions.

Against this background, our findings are surprising: at Gamma, code-switching behavior in knowledge-sharing interactions was felt to reduce exclusion and enhance inclusion in knowledge sharing. Our interviews strongly suggest that individuals code switch in knowledge-sharing interactions to accommodate those who have trouble interacting in the corporate or common language. Individuals proficient in the language of other knowledge-sharing participants quite often shift to their language to allow them to be part of the discussion and to let them express their opinions competently. Such code switching was seen as a practice that makes knowledge-sharing interaction more collaborative and inclusive. However, this type of code switching was possible only when knowledge-sharing participants had two common languages spoken by all or at least most of the team members; it allowed them to switch from one common language to another without excluding others from the discussion. One of the respondents, who was proficient in English and Spanish, explained that she commonly uses English for knowledge-sharing interactions with her team members but quite often switches to Spanish to explain complex issues to team members who are not very proficient in English. For example, as an expert in SAP, an Enterprise Resource Planning System used at Gamma, she often uses Spanish while helping others in SAP-related issues such as creation and integration of reports using several cost objects.

Knowledge-sharing participants also switch to noncorporate or native languages that are not understood by other knowledge-sharing participants. This type of switching is practiced in 
somewhat larger teams where different language communities are present. Knowledge-sharing participants switch away from the CCL to get help from other native language speakers in explaining or presenting their insights in a complex discussion. A Finnish marketing manager mentioned that her two Swedish-speaking team members often switch to Swedish and consult each other to be able to explain something in English, for example the integration of IP-targeted advertising into an account-based marketing plan for the North American market. Nevertheless, no one on the team has ever shown any resentment of this behavior, nor do they feel threatened or excluded. Such switching is usually short and requires that the conversation is explained in the CCL later to include others. A similar type of pragmatic motivation was also noted by Harzing and Feely (2008:55) who found that individuals switch to their native language just to ensure they have correctly understood a point and "to realign themselves" before they move on to the next critical point in discussion. According to the respondents, they do not mind such switching because it is helpful in ensuring that all voices and insights have been gathered, and that an informative decision has been taken. In short, it is much better to switch and express oneself than stick to one language and remain silent due to fear of being linguistically incompetent in expressing one's views. It does not only depict the sensitivity to language diversity, but also trust that the language will not be used for purposive exclusion. This is completely in line with Mayer, Davis and Schoorman's (1995) seminal definition of interpersonal trust as a willingness to be vulnerable to the actions of the other party, which in turn has been found to be extremely important for knowledge sharing (see e.g. Zaheer, McEvily and Perrone 1998).

There was a strong perception among respondents that code switching is more of a collaborative than an exclusionary practice. Teams that have been together for a long time have developed a linguistic culture in which code switching is openly encouraged as long as it helps to keep everyone involved during knowledge-sharing interactions and generates productive discussions. The positive perception of code switching in knowledge-sharing interactions in the presence of interpersonal trust is clearly visible in the following quotes:

"The plus [of code switching] is that if there are some things that someone is not able to explain in a good way in English then this person may switch to another language. It is a big plus that you are able to convey your point whether you use English or Finnish." (Respondent 10)

This kind of understanding, again supported by the organization through a relaxed language policy and training, was a strong informal norm clearly driven by a shared will to achieve successful knowledge-sharing interactions. There was a high level of awareness that exclusion of voices in knowledge-sharing interactions due to language competency differences could damage the performance of the entire team (Adler \& Gundersen, 2002), reflecting negatively on the reputation of the team rather than on a single individual. Therefore, knowledge-sharing participants saw strict adherence to one language as a danger to productive knowledge-sharing interaction. One of the respondents mentions that he often shifts to Arabic to accommodate two Arabic-speaking members of the team while discussing, for example, revisions to contracts and implementations. He further states:

"Many very genius people with good expertise will not be able to put their point through [if no code switching is allowed]." (Respondent 3) 
Moreover, some respondents state that inflexibility toward the use of multiple languages in knowledge-sharing interactions can also be "problematic". Knowledge-sharing participants with strong proficiency in the common language could easily dominate discussions. They could get their arguments accepted because of their superior linguistic ability while others, who have low proficiency in the CCL, would experience loss of rhetoric prowess and, consequently, of their voice. Taking advantage of the low linguistic competency of others could effectively kill the very purpose of knowledge-sharing interaction, that is, the exchange of ideas and mutual learning. Moreover, the relationship between knowledge-sharing participants could become strained, diminishing future knowledge-sharing possibilities (Aichhorn \& Puck, 2017a).

In short, code switching during knowledge-sharing interaction is seen as a behavior that provides a level playing field among linguistically diverse knowledge sharing participants. This awareness existed widely at different levels of the organization, thereby shoring up the support for code switching. There was a strong awareness of potential drawbacks caused by using one language only, which was also promulgated by the management. Employees used code switching as an inclusionary rather than exclusionary practice in knowledge sharing interaction. This ability of employees to actively participate in knowledge sharing discussion, utilize their knowledge and be a productive team member further strengthened interpersonal trust among knowledge sharing participants at Gamma, in what we interpret as a virtuous circle empowering organizational members to attempt to contribute with their best insights even in the absence of full CCL fluency. Consequently, code switching was found to curtail asymmetric knowledge contribution in knowledge sharing interactions by reducing what Piekkari et al. (2014) call a silencing effect staying quiet during discussion due to lack of proficiency in the common language.

From a faultline perspective, what seems to underpin these sentiments is a shared view of code switching as a benign behavior aimed at optimal outcomes for the company, rather than optimizing on or benefiting from the ignorance of others. In the presence of this belief, code switching is accepted and even encouraged, and does not trigger latent faultlines even if others are momentarily excluded from the conversation. This holds true if and insofar as these others trust the potential vulnerability they incur through momentary lack of comprehension to not be used against them. However, as pointed out above, this is again based on strong norms and well-established practices such as switching only for short periods of time and explaining the conversation in CCL later on.

\subsection{Supporting knowledge contextualization}

Code switching is helpful for contextualization of knowledge, particularly when knowledgesharing interaction is conducted in the CCL language among linguistically diverse employees. The basic task in any kind of knowledge-sharing interaction is to convey to others the value and application of the knowledge being shared. The real knowledge sharing happens when knowledgesharing participants put forth their insights, instinctual knowledge and experiences in the common context so it is understandable to all. For example, when a team of engineers tries to solve an engine vibration issue, knowledge sharing is not simply about telling others what one knows about engine vibration. It involves communicating knowledge taking into consideration engine-related factors such as age, model and place of installation, as well as the other participants' characteristics such as area of specialty and experience. This contextualization of knowledge is the most critical 
and challenging aspect of knowledge sharing (Ahmad, 2017; Holden \& von Kortzfleisch, 2004; Liyanage et al., 2009).

According to the respondents, linguistic diversity among knowledge-sharing participants negatively influences the contextualization process because significant cognitive resources are wasted on dealing with language-proficiency-related issues, not only of their own but also of others. Volk, Köhler, and Pudelko (2014) call it "brain drain", which can happen in knowledgesharing interactions when a participant's cognitive capability is depleted because most of their working memory (attention) is dedicated to correcting their usage of the non-native language rather than to task-related thinking and reasoning. Knowledge-sharing participants find code switching a useful strategy because it reduces brain drain. By switching to another language, employees try to avoid language-related thinking and focus on the different aspects of the knowledge-sharing situation. It helps them during the knowledge contextualization process because they can focus on discussing the matter in question, for example, when explaining to someone how to insulate a turbine from the hot gas stream in a faulty engine, rather than on language issues. One of the respondents analogized the knowledge-sharing interaction to open turbulent sea stating,

"For real deep diving [to develop a strong understanding], if you are not good enough with your language, you must switch to another language." (Respondent 17)

The analysis of the data shows that code switching helps knowledge contextualization in three ways. First, code switching allows code selection, that is, using the most appropriate language for discussing a topic whenever possible. Many respondents mentioned that some concepts can be expressed better in one language than in another. Similarly, some words from a specific language seemed more coherent and relevant to express an idea than others. For example, when a discussion shifts to local matters such as local laws on human resources and procurement-related legal requirements, the language of the discussion also changes.

"Normally the topics involving local policy, for example, local laws, labor laws, or things like that trigger language change." (Respondent 14)

This is because such local matters are written and expressed in the local language. Local governmental institutions make these laws and requirements not only using the local language but also applying it to the local context. Therefore, explaining these types of topics in another language, such as English, requires considerable effort. Some concepts are coded in the language in which they were written and learned and, for that reason, are more accessible when the same language is used for retrieval (Hadjichristidis et al., 2016). The knowledge-sharing participants mentioned that switching to the original language of the content is a useful strategy for building constructive and efficient discussions. The absence of switching means extra effort for translating, which though not impossible, would waste time and energy and distract knowledge-sharing participants from the real problem under discussion. Moreover, not switching languages does not add any value to the knowledge-sharing interaction, as one of the interviewees said:

"It is quite useless. It does not make sense . . and it would not add anything or value in our discussion, for example, regarding solving a problem.” (Respondent 13) 
Second, code switching also helps in knowledge contextualization, specifically in searching for the words to describe a problem. The analysis shows that knowledge-sharing participants quite often end up in a situation where they forget a word or a lexical unit in the middle of knowledgesharing interaction. Many interviewees underlined word search as a common phenomenon. One of the employees stated:

"I do not always know or remember the words to describe my situation, particularly when I am under pressure, for example, while discussing production problems with engineers. " (Respondent 11)

Although word search situations can arise in any kind of interaction, it was considered problematic specifically in knowledge-sharing interactions because they break the chain of thought and the flow of the interaction. It is not only embarrassing but it also shifts one's thinking from the content of the discussion to finding the right word. Instead of figuring out the right word, it is better to simply add the word from another language:

"Sometimes in the middle of critical discussion it happens that I cannot remember the word in English or Spanish, then I can use another language, for example, with my Dutch colleagues I sometimes use German words. " (Respondent 4)

Most of the time, other knowledge-sharing participants, e.g. for example, Dutch employees in the aforementioned case,- - understand the code-switched words due to their previous experience and understanding of the language. Consequently, the knowledge-sharing interaction continues without any distraction. However, if the code-switched word or sentence is not understood by other knowledge-sharing participants, explanation in English is required. Even though there is always the possibility that the code-switched content has to be explained later in the CCL, employees practiced code switching because even if they do not switch, they have to give an explanation about the forgotten word anyway. One of the Finnish interviewees called such code switching "trying your luck," since sometimes it works and sometimes it does not. But if it works, they may do away with the extra work of explaining and instead focus on the critical matters at hand.

Third, code switching helps knowledge contextualization through message reiteration. Many respondents mentioned that repeating critical points is a common strategy for building a shared understanding of a topic or problem. For example, after explaining a complex process such as abrasive blasting, a knowledge-sharing participant repeats the important points of the entire process. Similarly, a team leader can summarize the discussion to clarify the progress being made. Furthermore, knowledge-sharing participants' language diversity provides an extra option for message reiteration through code switching - the message is not repeated in the same language but in a different one. Thus, knowledge-sharing participants can decipher the meaning and make sense of critical information better when repeated in two different codes. It is helpful in reinforcing and clarifying the message particularly when "it has already been transmitted in one code, but not understood properly" (Eldrige, 1996:306). This also represents a collective effort to use diverse language resources that are at knowledge sharing participants' disposal to enhance knowledge sharing quality. Moreover, it shows a strong norm of language accommodation, and a positive attitude toward multilingualism and its productive utilization in knowledge sharing interactions. 
In short, code switching reduces cognitive load and helps knowledge contextualization by making knowledge-sharing interaction more efficient. Rather than worrying about task-irrelevant nuances created by language diversity, knowledge-sharing participants are able to spend more cognitive resources on building a useful dialogue by sharing their opinions, making it more likely that knowledge sharing will be successful. From a faultline perspective, this emphasis on dialogue oriented toward achieving a common goal means that instances of code switching are not interpreted as being of negative intent, whereby interlocutors can avoid activating the latent faultlines that certainly are often present in these situations.

\section{Discussion}

In contrast to most previous research on code switching in knowledge sharing in MNCs (e.g., Harzing \& Feely, 2008; Neeley et al., 2012; Tenzer et al., 2014), the present study indicates that code switching is not necessarily merely a form of linguistic interference. It can also be intended -and often functions - as a strategic behavior that helps build efficient and successful knowledgesharing interactions by drawing on multiple languages. Specifically, we find that code switching supports knowledge-sharing interactions between linguistically diverse employees in three ways: (i) it helps them develop and maintain a standardized technical vocabulary, (ii) it makes knowledge sharing more inclusive, and (iii) it enhances the contextualization of knowledge.

The development and maintenance of a standardized technical vocabulary during knowledgesharing interactions supports knowledge-sharing through its critical role in decoding, articulating and translating knowledge. A standardized vocabulary provides consistency in knowledge-sharing interactions conducted in other languages than the CCL, lowering the risk of word loss and confusion. As for how code switching helps make knowledge sharing more inclusive, we find that shifting between different languages in knowledge-sharing interactions can help compensate for imbalances in participants' CCL proficiency, thereby making their interactions more collaborative and constructive. Finally, code switching enhances knowledge contextualization by helping reduce language-related distractions, as individuals can select the appropriate language for discussing specific topics, solving word-search problems and reiterating messages. In short, code switching acts as a corrective mechanism that ensures cognitive resources are not exhausted by dealing with issues related to language diversity, and hence can be devoted to what is necessary, that is, knowledge explanation and comprehension.

Reconciling these findings with previous research that takes a negative view of code switching highlights the role of pragmatism in leveraging the potential benefits of code switching during knowledge-sharing interactions. Successful knowledge sharing is important for job security, career advancement and improving performance. Disapproving of code switching may result in vocabulary loss, exclusion of insights from linguistically deficient participants and waste cognitive resources. These constitute important reasons for knowledge-sharing participants to ignore the negative aspects of code switching and focus more on its benefits.

Then why is it that code switching is not always problematic? The faultline perspective we have applied in this paper helps discern certain boundary conditions for this. The Faultline Theory (Lau \& Murnighan, 1998, 2005) holds that characteristics constituting latent dividing lines between subgroups may exist in any group, and when they are activated, subgroups tend to form along 
them, leading to heightened conflict and reduced trust between subgroups. However, which characteristics will be activated - if indeed any - is a cognitive social process (Homan et al., 2007; Jehn et al., 2009; Jehn and Bezrukova, 2010), meaning that the outcome is not predetermined. It is also contextually embedded, meaning that it is influenced by factors such as organizational culture.

Our empirical results suggest that at Gamma, as opposed to other cases documented in prior research (e.g. Hinds et al., 2014), variation in language skills was not active as a characteristic that generated dividing lines among employees. The absence of active language-based faultlines, along with commonly accepted and vigorously enforced organization-level language norms, allowed interlocutors to trust that others' code switching held no malicious intent and enabled them to interpret it primarily in practical terms. Formal approval of multilingual communication and a flexible CCL policy helped legitimate employees' tendency to leverage their diverse linguistic skills during knowledge sharing in the three ways we have described earlier. Intention to switch was not interpreted negatively because Gamma staff, based on accrued experience and support by organizational policy, believed that code switching would not be used for pursuing hidden agendas, such as exclusion of others' opinions during knowledge sharing interactions. At the same time, employees proactively, assiduously and collectively maintained a shared base of understanding in the form of a core technical vocabulary in English.

Why did this pattern emerge in Gamma but not in other cases studied in prior research? We suggest that this is due to the history and organization of the company. Faultline research has found that groups' tendency to split along salient characteristics can be buffered by organizational mechanisms. Subgroups are likely to persist once they have formed, particularly if they are limited in number and similar influence (Lau \& Murnighan, 1998; see also Polzer et al., 2006), but such competition among a few centers of power did not feature prominently at Gamma due to its extensive decentralization. Nor were there strong tensions between HQ and subsidiaries, as HQ had historically taken a pluralistic approach towards the subsidiaries under its remit. Our interpretation is that these circumstances had helped keep linguistic differences non-salient as a basis for subgroup formation. This tendency was further supported by a relatively high level of identification with Gamma across units, in line with Jehn and Bezrukova's (2010) finding that the extent of subgroup members' identification with a 'meta-identity' that stretches across faultlines tends to moderate the impacts of faultlines on group processes.

Overall, we believe that attitudes vis-à-vis code switching at Gamma can be understood in terms of a self-reinforcing loop of interpersonal trust, code switching and knowledge sharing, embedded in an organizational context with strong norms that encouraged, and to a certain extent, even forced individual actors to ignore potential faultlines. Knowledge sharing abetted by code switching requires a certain level of trust, but when successful, it also reinforces trust and facilitates further knowledge sharing. Six and Sorge (2008) argue that individuals demonstrate their trustworthiness by signaling the ability to perform according to the expectations of relevant others, and the intention to do so in the future as well. These signals, known as positive relational signals (Lindenberg 1997, Wittek 1999), engender positive affect on other actors and hence perpetuate or reinforce trust. We believe that code switching sends positive relational signals as it allows individuals to see its benefits in practice (Wittek, 1999). The organization plays a critical role in 
the generation and inference of such signals by managing the context of this process so that certain interpretations are supported and others are seen as irrelevant. Figure 1 summarizes these findings.

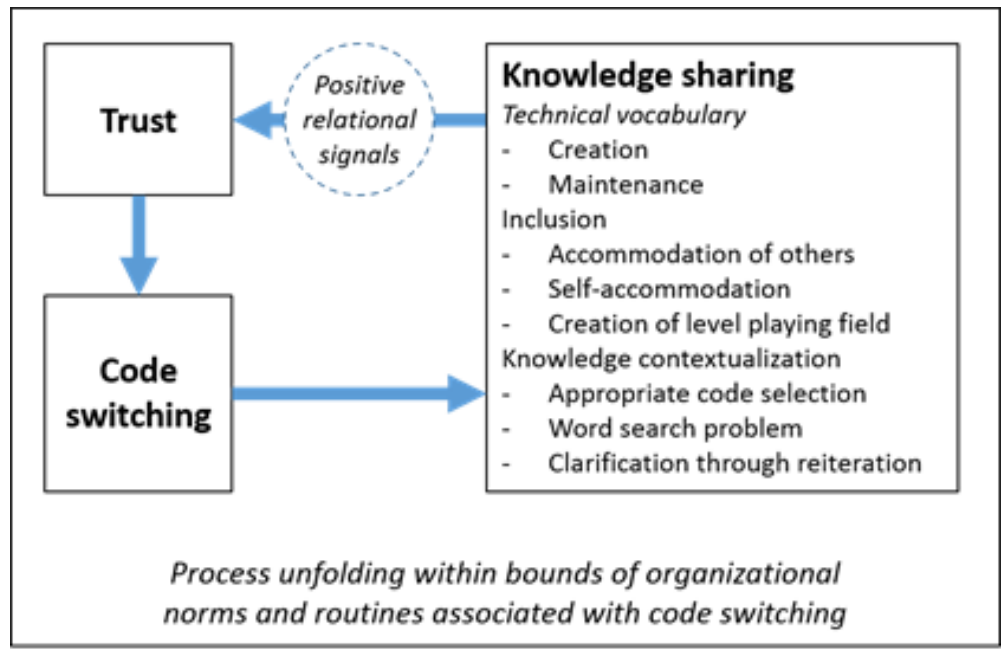

Figure 1: Summary of findings

\section{Conclusion}

Operating in a multilingual environment adds significant complexity to knowledge-sharing interactions, even when participants can draw upon a widely spoken common corporate language. Our findings offer significant insights into how MNC employees handle this complexity, where using multiple languages is not only a factor that complicates their knowledge-sharing interactions but also plays an important role in solving communication-related problems. Language diversity undeniably increases the ambiguity and complexity of knowledge-sharing interactions in MNCs (e.g., Ahmad, 2017; Feely \& Harzing, 2003), making adjustments in linguistic behavior imperative for the success of these interactions. Based on the findings in this study, we propose that code switching plays a key role among these linguistic adjustments.

Our respondents' positive assessments of code-switching behaviors for knowledge sharing purposes underlines the importance of adjusting linguistic behavior to the affordances and constraints of participants' linguistic capability as well as corporate language policies. Granted, at Gamma such adjustments were undertaken within the bounds of strong norms and established practices helping maintain an inclusive climate, such as code switching only briefly and following up with an explanation of what was said. Prior research (e.g., Neeley, Hinds \& Cramton, 2012, Tenzer \& Pudelko 2015) strongly suggests that if such norms are not adhered to, e.g. some interaction partners switch codes for a significant part of the conversation, the positive impacts of code switching will quickly deteriorate. Yet even with this caveat, we argue that some purposes of code switching in knowledge-sharing interactions cannot be achieved through any other communicative strategy. For example, it is the only strategy that provides a quick fix for linguistic deficiencies in knowledge-sharing interactions and helps to perform responsibilities related to knowledge transfer. Without code switching, linguistically less skilled individuals have no other option but to stay quiet or abstain from attending knowledge-sharing interactions. 


\subsection{Theoretical contributions}

By underlining the positive impacts of code switching on knowledge-sharing interactions, this study makes a significant contribution to existing research on how language influences knowledge sharing in multilingual organizations in general (Ahmad \& Widén, 2015; Lüdi et al., 2013), and specifically in MNCs (Lauring \& Selmer, 2011; Mäkelä, et al., 2007; Marschan-Piekkari et al., 1999). Previous research suggests that acceptance of language diversity enables a broader range of individuals to contribute their diverse insights and viewpoints, which can be useful for challenging taken-for-granted assumptions and can lead to a more productive knowledge-sharing dialogue (Lüdi et al., 2013). The findings in this study suggest that tolerance of language diversity potentially contributes more to successful communication than diverse insights. Linguistic behaviors such as code switching can enhance the quality of knowledge sharing through interaction patterns such as repetition of messages in multiple languages and confirmation of understanding among colleagues in their own native language. Such interaction patterns can bring valuable depth to knowledge-sharing interactions by sensitizing actors to misinterpretations and superficial understandings.

Consistent with recent research on knowledge sharing between speakers of different languages in MNCs (e.g. Aichhorn, \& Puck, 2017b; Ahmad, 2017; Lauring \& Selmer, 2011; Schomaker, \& Zaheer, 2014), this study supports the view that successful knowledge sharing does not solely depend on CCL competency. While a certain level of competency in a shared or corporate language is a threshold requirement for knowledge sharing, this study shows that knowledge and skillful use of other complementary languages are also very important. It is rare that individuals develop native-level proficiency in foreign languages, which means there will always be some deficiency and variance in employees' linguistic competency. Due to the collaborative and interactive nature of interpersonal knowledge sharing in multilingual MNC environments, it is not always one's own linguistic competency that matters for successful knowledge-sharing interactions, but also that of others. Many respondents reported switching to the language(s) of other participants during the knowledge-sharing process, underlining that code switching also provides a mechanism for accommodating others' relative lack of linguistic skills; this also emphasizes that competency in other languages besides the corporate one is extremely important for knowledge sharing between linguistically diverse individuals. This makes these skills highly relevant for MNCs, given their dependence on successful knowledge sharing and the multilingual nature of their workforce.

Moreover, if such linguistic patterns are accepted in multilingual knowledge-sharing interactions, they could become habitual and potentially be useful in interactions that would otherwise be carried out monolingually. It is not difficult to imagine a situation where a group of actors sharing knowledge in their native language would ameliorate or deepen their interaction by code switching into a foreign language. Exploring this possibility constitutes an obvious suggestion for future research.

Quite often nonnative speakers enter discussions insecure and unconfident because of their constrained ability to interact in a foreign language (Aichhorn \& Puck, 2017a). Limited semantic transferability and lingua-cultural differences in discourse practice can make multilingual knowledge sharing a stressful activity. Moreover, emotional and identity crises regarding the usage of a specific foreign language could surface (Vaara et al., 2005). How employees develop successful knowledge-sharing interactions despite the challenges brought about by the need to 
operate across language boundaries is still a relatively underexplored area (Aichhorn, \& Puck, 2017b; Ahmad, 2017). A notable exception in this regard is the work of Sunaoshi, Kotabe, and Murray (2005). They showed how during technology transfer, American and Japanese production floor workers draw extensively on demonstrability and drawability techniques to counter linguistic and cultural distance. Our study contributes to this area of research by showing how code switching can be used to overcome some of the language-related issues in multilingual knowledge-sharing interactions.

In addition to identifying the positive aspects of code switching, this study also unravels the importance of mutual trust, organizational environment and its language-related policies which form the supportive conditions required to actualize positive implications of code switching for knowledge sharing. This constitutes an important contribution because, as pointed out by Aichhorn and Puck (2017b), previous research lacks clear understanding regarding the underlying supportive conditions and processes that drive positive implications of language diversity in cross-linguistic communication such as knowledge sharing.

\subsection{Limitations}

In terms of limitations, our primary data were collected through personal interviews; no observations were carried out. Observation provides the opportunity to notice subtle and subconscious aspects of linguistic behavior as they occur, and therefore could have been extremely useful in studying the impact of code switching on knowledge sharing. Nevertheless, the organization was sensitive regarding its privacy and therefore did not allow any observations especially of knowledge-sharing interactions.

Another limitation of this study is the inclusion of only non-native English speakers in the sample. English was the corporate language of the organization. A positive attitude toward code switching in knowledge-sharing interactions could be partially the result of the sympathy that non-native English speakers have for each other. Nevertheless, our sample is justified by the fact that most English speakers in the world are non-native, and the same holds true in MNCs (Crystal, 2003). In terms of language representation, we also see the over-representation of native Finnish speakers in our sample as a limitation.

In this study, half of the interviewees were low- and middle-level managers, which meant that many of them had good English language skills. On the one hand, this is a strength of our study. It shows that employees switch between languages even when they can speak the common corporate language fluently, which underlines the intentional nature and functional role of code switching in knowledge-sharing interaction. On the other hand, it is a limitation in that it overlooks the non-managerial workforce, often composed of local employees who use local languages to conduct day-to-day tasks and sometimes do not even speak the corporate language (BarnerRasmussen \& Aarnio, 2011). Such employees would be very sensitive to code switching, particularly to English, because they operate mostly in monolingual environments. Individuals who have knowledge of multiple languages or who are constantly exposed to multilingual environments tend to show a more positive attitude toward code switching than those who are monolingual or operate mostly in monolingual environments (Dewaele \& Wei, 2014). We suggest that future research focus on non-managerial employees as well as monolinguals to understand 
whether the role of code switching in knowledge sharing changes with employees' hierarchical position, as well as personal and environmental multilingualism.

\subsection{Practical implications}

In terms of practical implications, we argue first of all that MNCs should support mixed language use ("multilingual franca approach"; Janssens \& Steyaert, 2014), particularly in formal knowledge sharing interactions. In informal knowledge sharing interactions, knowledge sharing participants tend to be flexible toward language use (Tange \& Lauring, 2009), but in formal knowledge sharing interactions such as team meetings, there is more pressure to adhere to a one-language policy (Aichhorn \& Puck, 2017a). By officially allowing code switching, organizations can promote more participative knowledge-sharing interactions.

MNCs should also make an active effort to develop a culture of flexible language use. It is extremely important to eradicate negative perceptions regarding code switching among employees in order to reap its benefits in knowledge sharing. Sociolinguistic research tells us that the attitude toward code switching tends to shift and can become positive when individuals are able to grasp its potential benefits in social cohesion and communication (Montes-Alcalá, 2000; Penna, 2004). Keeping this in mind, it is important for organizations to educate employees on how code switching can enhance the effectiveness of information exchange. Internal communication channels, such as newsletters and intranets, can be used to publish successful experiences of employees' code switching.

Previous studies have suggested that MNCs should introduce training programs for improving knowledge-sharing experiences between employees (Cabrera \& Cabrera, 2005). Traditionally, the focus has been on communication skills such as how to increase clarity in knowledge-sharing interactions (Bischof \& Eppler, 2011). Our findings complement this view by indicating that MNCs could also use such training programs to teach how code switching can be used effectively for knowledge-sharing situations with linguistically and culturally diverse employees.

\section{References}

Ackerman, M. S., Pipek, V., \& Wulf, V. (2003). Sharing expertise: Beyond knowledge management MIT press. Adler, N. J., \& Gundersen, A. (2007). International Dimensions of Organizational Behavior (5. ed). Mason, Ohio: South-Western Cengage Learning.

Ahmad, F. (2017). Knowledge sharing in a non-native language context: Challenges and strategies. Journal of Information Science, 24(2), 248-264.

Ahmad, F., \& Widén, G. (2015). Language clustering and knowledge sharing in multilingual organizations: A social perspective on language. Journal of Information Science, 41(4), 430-443.

Ahmad, F., \& Widén, G. (2018). Knowledge sharing in multilingual organizations: Influence of code switching and convergence. European Journal of International Management, 12(2), 351-373.

Aichhorn, N., \& Puck, J. (2017a). “I just don’t feel comfortable speaking English”: Foreign language anxiety as a catalyst for spoken-language barriers in MNCs. International Business Review, doi:10.1016/j.ibusrev.2017.01.004

Aichhorn, N., \& Puck, J. (2017b). Bridging the language gap in multinational companies: Language strategies and the notion of company-speak. Journal of World Business, 52(3), 386-403.

Ambos, T. C., \& Ambos, B. (2009). The impact of distance on knowledge transfer effectiveness in multinational corporations. Journal of International Management, 15(1), 1-14.

Appel, R., \& Muysken, P. (2005). Language, contact and bilingualism. Amsterdam: Amsterdam Univ. Press.

Argote, L., \& Ingram, P. (2000). Knowledge Transfer: A basis for competitive advantage in firms. Organizational behavior and human decision processes, 82(1), 150-169.

Atkinson, P. (1996). Making sense of qualitative data: Complementary research strategies. Sage Publications. 
Atkinson, R., \& Flint, J. (2001). Accessing hidden and hard-to-reach populations: Snowball research strategies. Social Research Update, 33(1), 1-4.

Bailey, B. (2000). Social/interactional functions of code switching among Dominican Americans. Pragmatics, 10(2), 165-193.

Baker, C., \& Jones, S. P. (1998). Encyclopedia of bilingualism and bilingual education. Clevedon: Multilingual Matters.

Balam, O., \& de Prada Pérez, A. (2017). Attitudes toward Spanish and code-switching in Belize: Stigmatization and innovation in the Spanish classroom. Journal of Language, Identity \& Education, 16(1), 17.

Barner-Rasmussen, W., \& Aarnio, C. (2011). Shifting the faultlines of language: A quantitative functional-level exploration of language use in MNC subsidiaries. Journal of World Business, 46(3), 288-295.

Barner-Rasmussen, W., \& Björkman, I. (2007). Language fluency, socialization and inter-unit relationships in chinese and finnish subsidiaries. Management and Organization Review, 3(1), 105-128.

Barner-Rasmussen, W., \& Björkman, I. (2007). Language fluency, socialization and inter-unit relationships in Chinese and Finnish subsidiaries. Management and Organization Review, 3(1), 105-128.

Barner-Rasmussen, W., Ehrnrooth, M., Koveshnikov, A., \& Mäkelä, K. (2014). Cultural and language skills as resources for boundary spanning within the MNC. Journal of International Business Studies, 45(7), 886-905.

Bartlett, C. A., \& Ghoshal, S. (2002). Managing across borders: The transnational solution. Harvard Business Press.

Benson, E. J. (2001). The neglected early history of codeswitching research in the United States. Language \& Communication, 21(1), 23-36.

Bezrukova, K., Jehn, K. A., Zanutto, E., \& Thatcher, S. M. B. (2009). Do workgroup faultlines help or hurt? A moderated model of faultlines, team identification, and group performance. Organization Science, 20: 35-50.

Bischof, N., \& Eppler, M. J. (2011). Caring for clarity in knowledge communication. J.Ucs, 17(10), 1455-1473.

Björkman, A., \& Piekkari, R. (2009). Language and foreign subsidiary control: An empirical test. Journal of International Management, 15(1), 105-117.

Bot, C L J de, Broersma, M. E., \& Isurin, L. (2009). Sources of triggering in code-switching. In I. Ludmila, D Winford \& K D Bot (Ed.), Multidisciplinary Approaches to Code Switching (pp. 85-102). Amsterdam: John Benjamins Publishing.

Brannen, M. Y. (1994). "Your next boss is Japanese": Negotiating cultural change at a western Massachusetts paper plant. University of Massachusetts.

Brannen, M. Y. (2004). When Mickey loses face: Recontextualization, semantic fit, and the semiotics of foreignness. The Academy of Management Review, 29(4), 593-616.

Brannen, M. Y.,., Piekkari, R., \& Tietze, S. (2014). The multifaceted role of language in international business: Unpacking the forms, functions and features of a critical challenge to MNC theory and performance. Journal of International Business Studies, 45(5), 495-507.

Brown, S. A., Dennis, A. R., Burley, D., \& Arling, P. (2013). Knowledge sharing and knowledge management system avoidance: The role of knowledge type and the social network in bypassing an organizational knowledge management system. Journal of the Association for Information Science and Technology, 64(10), 2013-2023.

Bullock, B. E., \& Toribio, A. J. (2009). Themes in the study of code-switching. In B. E. Bullock, \& A. J. Toribio (Eds.), The Cambridge Handbook of Linguistic Code-switching (pp. 1-18). Cambridge: Cambridge University Press.

Cabrera, E. F., \& Cabrera, A. (2005). Fostering knowledge sharing through people management practices. The International Journal of Human Resource Management, 16(5), 720-735.

Chen, X., Li, X., Clark, J. G., \& Dietrich, G. B. (2013). Knowledge sharing in open source software project teams: A transactive memory system perspective. International Journal of Information Management, 33(3), 553-563.

Corbin, J., \& Strauss, A. (2008). Basics of qualitative research: Techniques and procedures for developing grounded theory (3rd ed.) Sage publications.

Creswell, J. W. (2012). Qualitative inquiry \&amp; research design (3rd ed.). Los Angeles: SAGE.

Crystal, D. (2003). English as a Global Language (2. ed). Cambridge: Cambridge Univ. Press.

Dalkir, K., \& Liebowitz, J. (2011). Knowledge Management in Theory and Practice. MIT press.

Deakin, H., \& Wakefield, K. (2014). Skype interviewing: Reflections of two PhD researchers. Qualitative Research, 14(5), 603-616.

Dewaele, J., \& Wei, L. (2014). Attitudes towards code-switching among adult mono-and multilingual language users. Journal of Multilingual and Multicultural Development, 35(3), 235-251. 
Dor, D. (2004). From Englishization to imposed multilingualism: Globalization, the internet, and the political economy of the linguistic code. Public Culture, 16(1): 97-118.

Eisenhardt, K. M. (1989). Building theories from case study research. Academy of Management Review, 14(4), 532550.

Eldridge, J. (1996). Code-switching in a Turkish secondary school. ELT Journal, 50(4), 303-311.

Eppler, M. (2007). Knowledge communication problems between experts and decision makers: An overview and classification. The Electronic Journal of Knowledge Management, 5(3), 291-300.

Feely, J. A., \& Harzing, A. (2003). Language management in multinational companies. Cross Cultural Management, 10(2), 37-52.

Foss, N. J., \& Pedersen, T. (2002). Transferring knowledge in MNCs: The role of sources of subsidiary knowledge and organizational context. Journal of International Management, 8(1), 49-67.

García, O., \& Wei, L. (2013). Translanguaging: Language, bilingualism and education. Basingstoke: Palgrave Macmillan.

Gardner-Chloros, P. (2009). Code-switching. Cambridge: Cambridge University Press.

Genesee, F. (2003). Rethinking bilingual acquisition. In J. M. Dewaele, A. Housen \& L. Wei, Bilingualism: Beyond basic principles (pp. 158-182). Clevedon: Multilingual Matters.

Gephart, R. P. (2004). Qualitative research and the academy of management journal. Academy of Management Journal, 47(4), 454-462.

Gertsen, M. C., \& Søderberg, A. M. (2012). Inpatriation in a globalising MNC: knowledge exchange and translation of corporate culture. European Journal of International Management, 6(1), 29-44.

Goldstein, T. (1997). Two languages at work bilingual life on the production floor. Berlin New York: Mouton de Gruyter.

Grant, R. M. (1996). Toward a knowledge-based theory of the firm. Strategic Management Journal, 17(S2), 109122.

Grosjean, F. (1989). Neurolinguists, beware! the bilingual is not two monolinguals in one person. Brain and Language, 36(1), 3-15.

Gullberg, M., Indefrey, P., \& Muysken, P. C. (2009). Research techniques for the study of code-switching. In B. E. Bullock, \& A. J. Toribio (Eds.), The Cambridge Handbook of Linguistic Code-switching (pp. 21-39). Cambridge: Cambridge University Press.

Gumperz, J. J. (1982). Discourse strategies Cambridge University Press.

Hadjichristidis, C., Geipel, J., \& Surian, L. (2016). How foreign language affects decisions: Rethinking the braindrain model. Journal of International Business Studies, 48(5), 645.

Hansen, M. T., Nohria, N., \& Tierney, T. (1999). What's your strategy for managing knowledge. Harvard Business Review, 77(2), 106-116.

Hardy, M. A. (2004). Handbook of data analysis. London: Sage.

Harzing, A., \& Feely, A. J. (2008). The language barrier and its implications for HQ-subsidiary relationships. Cross Cultural Management: An International Journal, 15(1), 49-61.

Harzing, A., Köster, K., \& Magner, U. (2011). Babel in business: The language barrier and its solutions in the HQsubsidiary relationship. Journal of World Business, 46(3), 279-287.

Hedlund, G. (1986). The hypermodern MNC-A heterarchy? Human Resource Management, 25(1), 9-35.

Hinds, P. J., Neeley, T. B., \& Cramton, C. D. (2013). Language as a lightning rod: Power contests, emotion regulation, and subgroup dynamics in global teams. Journal of International Business Studies, 45(5), 536-561.

Holden, N. J., \& Von Kortzfleisch, H. F. (2004). Why cross-cultural knowledge transfer is a form of translation in more ways than you think. Knowledge and Process Management, 11(2), 127-136.

Homan, A. C., van Knippenberg, D., Kleef, G. A., \& de Dreu, C. K. W. (2007). Bridging faultiness by valuing diversity: Diversity beliefs, information elaboration, and performance in diverse workgroups, Journal of Applied Psychology, 92(5): 1189-1199.

Hua, Z., \& Wei, L. (2005). Bi- and multilingual acquisition. In M. Ball (Ed.), Clinical sociolinguistics (pp. 165179). Oxford: Blackwell.

Huysman, M., \& De Wit, D. (2004). Practices of managing knowledge sharing: Towards a second wave of knowledge management. Knowledge and Process Management, 11(2), 81-92.

Ipe, M. (2003). Knowledge sharing in organizations: A conceptual framework. Human Resource Development Review, 2(4), 337-359.

Janssens, M., \& Steyaert, C. (2014). Re-considering language within a cosmopolitan understanding: Toward a multilingual franca approach in international business studies. Journal of International Business Studies, 45(5), 623-639. 
Janssens, M., Lambert, J., \& Steyaert, C. (2004). Developing language strategies for international companies: The contribution of translation studies. Journal of World Business, 39(4), 414-430.

John, L., \& Lyn, L. (1994). Analyzing social settings: A guide to qualitative observation and analysis. Belmont, CA: Wadsworth.

Jørgensen, J. N. (2008). Polylingual languaging around and among children and adolescents. International Journal of Multilingualism, 5(3), 159-275.

Klitmøller, A., \& Lauring, J. (2013). When global virtual teams share knowledge: Media richness, cultural difference and language commonality. Journal of World Business, 48(3): 398-406.

Lauring, J. (2008). Rethinking social identity theory in international encounters. International Journal of Cross Cultural Management, 8(3), 343-361.

Lauring, J. (2009). Managing cultural diversity and the process of knowledge sharing: A case from Denmark. Scandinavian Journal of Management, 25(4), 385-394.

Lauring, J., \& Selmer, J. (2011). Multicultural organizations: Common language, knowledge sharing and performance. Personnel Review, 40(3), 324-343.

Lindenberg, S.M. (1997): Grounding groups in theory: functional, cognitive and structural interdependencies. Advances in Group Processes, 14: 281-331.

Liyanage, C., Elhag, T., Ballal, T., \& Li, Q. (2009). Knowledge communication and translation-a knowledge transfer model. Journal of Knowledge Management, 13(3), 118-131.

Lüdi, G., Höchle, K., \& Yanaprasart, P. (2013). Multilingualism and diversity management in companies in the upper rhine region. In A. C. Berthoud, F. Grin \& G. Lüdi. Exploring the dynamics of multilingualism: The DYLAN project. Amsterdam: Benjamins.

Mäkelä, K. (2007). Knowledge sharing through expatriate relationships: A social capital perspective. International Studies of Management \& Organization, 37(3), 108-125.

Mäkelä, K., Kalla, H. K., \& Piekkari, R. (2007). Interpersonal similarity as a driver of knowledge sharing within multinational corporations. International Business Review, 16(1), 1-22.

Marschan-Piekkari, R., Welch, D., \& Welch, L. (1999a). Adopting a common corporate language: IHRM implications. International Journal of Human Resource Management, 10(3), 377-390.

Marschan-Piekkari, R., Welch, D., \& Welch, L. (1999b). In the shadow: The impact of language on structure, power and communication in the multinational. International Business Review, 8(4), 421.

Brannen, M. Y. (2004). When mickey loses face: Recontextualization, semantic fit, and the semiotics of foreignness. The Academy of Management Review, 29(4), 593-616.

Mayer, R. C., Davis, J. H., and Schoorman, F. D. (1995). An Integrative Model of Organizational Trust. Academy of Management Review, 20: 709-734.

Milosevic, I., Bass, A. E., \& Combs, G. M. (2015). The paradox of knowledge creation in a high-reliability organization. Journal of Management, doi:10.1177/0149206315599215

Montes-Alcalá, C. (2000). Attitudes towards oral and written codeswitching in Spanish-English bilingual youths. In A.Roca (Ed.), Research on Spanish in the U.S (pp. 218-227). Somerville, CA: Cascadilla.

Myers-scotton, C., \& Bolonyai, A. (2001). Calculating speakers: Codeswitching in a rational choice model. Language in Society, 30(1), 1-28.

Nadayama, N. (2018). Isolated foreign subsidiary's initiative in knowledge transfer within the MNE. Journal of International Management. Advance online publication. doi.org/10.1016/j.intman.2018.10.002

Neeley, T. B., Hinds, P. J., \& Cramton, C. D. (2012). The (un)hidden turmoil of language in global collaboration. Organizational Dynamics, 41(3), 236-244.

Neeley, T. B. (2013). Language matters: Status loss and achieved status distinctions in global organizations. Organization Science, 24(2), 476-497.

Nilep, C. (2006). 'Code switching'in sociocultural linguistics. Colorado Research in Linguistics, 19(1), 1-22.

Nonaka, I., \& Takeuchi, H. (1995). The knowledge-creating company: How Japanese companies create the dynamics of innovation. Oxford university press.

Nunan, D., \& Carter, R. (2001). Teaching English to speakers of other languages. Cambridge, CUP,

Patton, M. Q. (2002). Qualitative evaluation and research methods (3rd ed.) Sage.

Peltokorpi, V. (2017). Absorptive capacity in foreign subsidiaries: The effects of language-sensitive recruitment, language training, and interunit knowledge transfer. International Business Review, 26(1), 119-129.

Peltokorpi, V. (2015). Corporate language proficiency and reverse knowledge transfer in multinational corporations: Interactive effects of communication media richness and commitment to headquarters. Journal of International Management, 21(1), 49-62. 
Pena Díaz, C. (2004). What do bilinguals think about their "code-switching"? RAEL: Revista Electrónica De Lingüística Aplicada, (3), 146-157.

Piekkari, R., \& Tietze, S. (2011). A world of languages: Implications for international management research and practice. Journal of World Business, 46(3), 267-269.

Piekkari, R., Oxelheim, L., \& Randøy, T. (2015). The silent board: How language diversity may influence the work processes of corporate boards. Corporate Governance: An International Review, 23(1), 25-41.

Piekkari, R., Welch, D. E., Welch, L. S., Peltonen, J., \& Vesa, T. (2013). Translation behaviour: An exploratory study within a service multinational. International Business Review, 22(5), 771-783.

Ribeiro, R. (2007). The language barrier as an aid to communication. Social Studies of Science, 37(4), 561-584.

Ritchie, W. C., \& Bhatia, T. K. (2013). Social and psychological factors in language mixing. In T. Bhatia, \& W. Ritchie (Eds.), The handbook of bilingualism and multilingualism (pp. 375-391) Wiley-Blackwell.

Robinson, O. C. (2014). Sampling in interview-based qualitative research: A theoretical and practical guide. Qualitative research in psychology, 11(1), 25-41.

Rose, S. (2006). The functions of codeswitching in a multicultural and multilingual high school. Stellenbosch University. Retrieved from http://hdl.handle.net/10019.1/2084

Sager, J. C., Dungworth, D., \& McDonald, P. F. (1980). English special languages: Principles and practice in science and technology. Wiesbaden: Brandstetter.

SanAntonio, P. M. (1987). Social mobility and language use in an american company in japan. Journal of Language and Social Psychology, 6(3-4), 191-200.

Schau, H. J., Dellande, S., \& Gilly, M. C. (2007). The impact of code switching on service encounters.Journal of Retailing, 83(1), 65-78.

Schomaker, M. S., \& Zaheer, S. (2014). The role of language in knowledge transfer to geographically dispersed manufacturing operations. Journal of International Management, 20(1), 55-72.

Six, F. \& Sorge, A. (2008): Creating a high-trust organization: An exploration into organizational policies that stimulate interpersonal trust building. Journal of Management Studies 45 (5): 857-883. DOI: 10.1111/j.14676486.20007.00763.x.

Skiba, R. (1997). Code switching as a countenance of language interference. The Internet TESL Journal, 3(10), 1-6.

Søderberg, A. M. (2015). Recontextualising a strategic concept within a globalising company: a case study on Carlsberg's 'Winning Behaviours' strategy. The International Journal of Human Resource Management, 26(2), 231-257.

Stell, G., \& Yakpo, K. (2015). Elusive or self-evident? looking for common ground in approaches to codeswitching. In G. Stell, \& K. Yakpo (Eds.), Code-switching between structural and sociolinguistic perspectives (pp. 1-16). Berlin, München, Boston: DE GRUYTER.

Steyaert, C., Ostendorp, A., \& Gaibrois, C. (2011). Multilingual organizations as 'linguascapes': Negotiating the position of english through discursive practices. Journal of World Business, 46(3), 270-278.

Sunaoshi, Y., Kotabe, M., \& Murray, J. Y. (2005). How technology transfer really occurs on the factory floor: a case of a major Japanese automotive die manufacturer in the United States. Journal of World Business, 40(1), 57-70.

Tange, H., \& Lauring, J. (2009). Language management and social interaction within the multilingual workplace. Journal of Communication Management, 13(3), 218-232.

Tenzer, H., Pudelko, M., \& Harzing, A. (2014). The impact of language barriers on trust formation in multinational teams. Journal of International Business Studies, 45(5), 508-535.

Tenzer, H., Terjesen, S., \& Harzing, A. W. (2017). Language in international business: A review and agenda for future research. Management International Review, doi:10.1007/s11575-017-0319-x

Tietze, S. (2010). International managers as translators. European J. of International Management, 4(1), 184-199.

Usunier, J. (1998). International and cross-cultural management research. London: Sage.

Vaara, E., Tienari, J., Piekkari, R., \& Säntti, R. (2005). Language and the circuits of power in a merging multinational corporation. Journal of Management Studies, 42(3), 595-623.

Volk, S., Kohler, T., \& Pudelko, M. (2014). Brain drain: The cognitive neuroscience of foreign language processing in multinational corporations. Journal of International Business Studies, 45(7), 862-885.

Wang, S., \& Noe, R. A. (2010). Knowledge sharing: A review and directions for future research. Human Resource Management Review, 20(2), 115-131.

Wardhaugh, R. (2011). An introduction to sociolinguistics. Singapore: John Wiley \& Sons.

Wei, L., \& Wu, C. (2009). Polite Chinese children revisited: Creativity and the use of codeswitching in the chinese complementary school classroom. International Journal of Bilingual Education and Bilingualism, 12(2), 193211. 
Weinreich, U. (1968). Languages in contact, findings and problems. The Hague: Walter de Gruyter.D., Welch, C., Piekkari, R. (2005). Speaking in tongues: The importance of language in international management processes. International Studies of Management \& Organization, 35(1), 10-27.

Welch, C., Piekkari, R., Plakoyiannaki, E., and Paavilainen-Mäntymäki, E. (2011). Theorising from case studies: Towards a pluralist future for international business research. Journal of International Business Studies, 42(5): 740-762.

Welch, D.E. and Welch, L.S. (2015). Developing multilingual capacity: A challenge for the multinational enterprise. Journal of Management. DOI: 10.1177/0149206315594846.

Wittek, R.P.M. (1999). Interdependence and Informal Control in Organizations. Groningen: University of Groningen.

Yamao, S., \& Sekiguchi, T. (2015). Employee commitment to corporate globalization: The role of english language proficiency and human resource practices. Journal of World Business, 50(1), 168-179.

Yamao, S., Cieri, H. D., \& Hutchings, K. (2009). Transferring subsidiary knowledge to global headquarters: subsidiary senior executives' perceptions of the role of HR configurations in the development of knowledge stocks. Human Resource Management, 48(4), 531-554.

Yin, R. K. (2009). Case study research: Design and methods (5th ed.), Thousand Oak: Sage publications.

Zaheer, A., McEvily, B., and Perrone, V. (1998). Exploring the Effects of Interorganizational and Interpersonal Trust on Performance. Organization Science, 9: 141-159.

Wang, Q., Clegg, J., Gajewska-De Mattos, H., \& Buckley, P. (2018). The role of emotions in intercultural business communication: Language standardization in the context of international knowledge transfer. Journal of World Business. Advance online publication. doi.org/10.1016/j.jwb.2018.11.003. 